\title{
About Once Weekly
}

National Cancer Institute

\section{Source}

National Cancer Institute. About Once Weekly. NCI Thesaurus. Code C118853.

Scheduled or occurring at a frequency of approximately once per week. 